\title{
PSYCHOANALYSIS AND PSYCHOANALYTIC PSYCHOTHERAPY IN \\ UKRAINE DURING THE COVID-19 PANDEMIC UNFOLDING: THE RESULTS OF PRACTITIONERS' SURVEY
}

\author{
Mariana Velykodna ${ }^{1}$, Halyna Tsyhanenko ${ }^{2}$ \\ ${ }^{1}$ PhD, Clinical Psychologist, Psychoanalyst, Head of the Division «Psychoanalytic Psychology and Psychotherapy» in \\ the National Psychological Association of Ukraine, Kyiv, Ukraine; Senior lecturer, Department of Practical Psychology, \\ Kryvyi Rih State Pedagogical University, Kryvyi Rih (Ukraine) \\ ORCID ID: https://orcid.org/0000-0001-6269-793X \\ ${ }^{2}$ PhD, Psychologist, Senior Researcher, Associate Professor, State University of Economics and Technology, Kryvyi Rih \\ (Ukraine) \\ ORCID ID: https://orcid.org/0000-0003-1950-157X
}

UDC: 159.964

\begin{abstract}
The paper presents some specifics of psychoanalytic practice in the context of the COVID-19 pandemic unfolding, based on the results of the survey of 71 Ukrainian psychoanalysts and psychoanalytic psychotherapists after a month of lockdown. The majority of respondents tried to continue their practice in new conditions, the more experienced practitioners were more successful. However, 1/6 of the respondents had to suspend their practice. Those who continued practicing noted that their patients had experienced new intense feelings, mostly fear, anxiety, being "castrated", aggression and anger, hope and hopelessness. About a half of the respondents mentioned complementary changes in transference and countertransference, which was also associated with the duration of practical experience, certification status, guidelines from psychoanalytic associations, and patients' readiness to speak on pandemic-related or quarantine-related topics. While the majority of respondents confirmed perceived support from colleagues, they were chiefly dependent on associations' attentiveness and, surprisingly, the main method.
\end{abstract}

Keywords: Covid-19, Pandemic, Psychoanalytic Psychotherapy, Psychoanalysis, Ukraine.

Introduction. In the context of the worldwide COVID-19 pandemic unfolding and consequential quarantines in the most of affected countries, practitioners in various fields of psychological support and psychotherapy were facing new extraordinary and unavoidable conditions. Such developments required urgent decisions to be made regarding either changes in the organization of practice, or its suspension altogether. The surveyed psychologists and psychotherapists using different approaches noticed that, during the first cases of novel coronavirus in the region, practitioners from the Eastern Europe (53.1\% from Ukraine) had observed or implemented certain changes and modifications in their practice, e.g., the remote format of sessions, financial re-agreements, reshaping the purposes of their interven- tions towards coping with psychological outcomes of quarantine restrictions and towards self-support, etc. (Velykodna, Frankova, 2020). These changes may have significant consequences for psychoanalytic phenomena and the psychoanalytic setting as a whole, and therefore should be reconsidered. The clinical observations of the unfolding unconscious processes, manifested in predominant feelings, free associations, and transferencecountertransference dynamics are no less important.

Analysis of current evidence. From the beginning of the pandemic, psychoanalysts have been actively discussing the observed impact of the novel coronavirus, along with governmental policies and imposed quarantines, on the personal and social life of a patient - not only in the form of

Address for correspondence, e-mail: editpsychas@gmail.com Copyright: (C) Mariana Velykodna, Halyna Tsyhanenko

This is an Open Access journal, all articles are distributed under the terms of the Creative Commons Attribution-NonCommercial-ShareAlike 4.0 International (CC BY-NC-SA 4.0) License (http://creativecommons.org/licenses/by-nc-sa/4.0/), allowing third parties to copy and redistribute the material in any medium or format and to remix, transform, and build upon the material, provided the original work is properly cited and states its license. 
DOI (Issue): https://doi.org/10.31108/1.2021.7.1

published works (i.e., in journals) but also in short essays on social media, personal blogs, online-seminars and in private conversations. In Ukraine, two-thirds of the surveyed psychoanalysts and psychoanalytic psychotherapists admitted that due to the COVID-19 pandemic unfolding they had been searching for relevant theoretical conceptions related to (a) individual psychic response to the pandemic and lockdown, (b) social or psychic response, (c) ways to keep psychoanalytic stance, (d) particular issues of patients manifested due to the COVID-19 crisis, (e) certain interventions, including non-analytic (Velykodna, Tsyhanenko, 2020).

Most published psychoanalytic works related to COVID-19 are devoted to the psychoanalysis of "mass pandemic psychology" and to reports of psychoanalytic practice. Thus, H. Steel (2020) considers common fears pertaining to COVID-19 in the context of fear of annihilation and fear of loss of love object. J. S. Blackman (2020) analyses typical unconscious defensive reactions (e.g. obsessive cleaning, counterphobic behavior, humor, and denial) and in-home conflicts as neurotic repetitions of unresolved childhood issues due to regression provoked by the pandemic. S. Benvenuto (2020) describes several unconscious fantasies and beliefs which are manifested during the COVID-19 crisis. The first belief is that children are more fragile than the elderly, which covers an unconscious hope that the elderly will die, and which S. Benvenuto insightfully comments on as one of the possible reasons why the government may feel the urge to actually support a growing state of fear during the pandemic; only the fear of their own deaths can cause young citizens to truly support social distancing for the sake of saving elderly people. The second belief manifests itself in the compulsive buying of toilet paper; whereby S. Benvenuto considers people to unconsciously associate pandemics with uncleanliness and impurity, i.e., in relation to the sin and feces. It may also be associated with the fact that the original meaning of the virus was a slimy, liquid poison, or venom (H. Zwart, 2018). Besides, S. Benvenuto analyzes the detestation and denial of numbers and statistics (e.g., fatal cases), in an attempt to disregard anything that is "inhuman", and "fake news" as collective paranoid productions based on unconscious beliefs of the society. J. Bolanos, J. Lucero \& F. B. Raz (2020) are reflecting on the pandemic effects from biologi-
Volume 7 Issue 1 (45) 2021

cal and humanistic viewpoints in the context of Lacan's concept of Truth and its relation to science. S. Western (2020) reflects on the unconscious meaning of the coronavirus in terms of Lacan's register of the Real, and claims that COVID-19 becomes a signifier of contagion in the situation of the traumatic intrusion of the Real. The author also notes that such an intrusion exposes the subject to the truth about the precarious and interdependently connected world. As J. Gentile (2020) supposes, the spreading of novel coronavirus provokes the experience of a strange disorder of temporality, a feeling of the Real Time, similar to Winnicott's fear of breakdown with its primitive agonies. Q. Zangrilli (2020) compares feelings caused by the COVID-19 pandemic with regression phantasmatically linked to the intrauterine stage, thereby activating archaic defense mechanisms. J. Dodds (2020) writes about "the viral uncanny" in terms of S. Freud's "uncanny" as a severe experience when something seems both strangely familiar (reminding of a repressed aspect of the subject) and frighteningly alien. The author notes that it may be produced if the borders erected between the living and the dead, human and nonhuman, are threatened, blurred, or erased (Dodds, 2020). A. Yuran (2020) believes that social psychic response to the COVID-19 with its excessive paranoid, obsessive and phobic symptomatology may refer to Freud's "Verwerfung" ("return of the rejected").

Some psychoanalysts were thinking more in line with the influence of the COVID-19 pandemic unfolding on the psychoanalytic process (e.g. Catz, Ferruta, Francesconi, Goisis, et al. 2020; Rossi, Ferro, 2020; Rowlandson, 2020; Lesley, 2020; Lippin, 2020). For instance, N. McWilliams (2020) reports her observations about a patient's belief that their psychoanalyst is an omnipotent, omniscient Other, who can fix the situation if he or she will see the patient's pain. Besides, N. McWilliams highlights the importance of accepting the realistic, non-neurotic status of patients' fears and losses in relation to the coronavirus. D. Elise (2020) considers how the COVID-19 crisis affects the libidinal vitality of the analytic couple due to the situation, which becomes an obstacle for two erotic bodies to meet in a room, in terms of de-libidinization of the analytic erotic field (Elise, 2019). S. Keggereis (2020) reflects on the challenges of working psychoanalytically when a physical level of the "good object" (in Klien's terms, 1932) - our body 
and, especially, immune system - is hard to trust, and when "good parents" (at least, some reliable political leaders) are absent either. Therefore, it transforms a common psychoanalytic aim to offer a good object to our patients into a challenge. Based on her own clinical observations, M. Velykodna (2021) describes her difficulties in using countertransference and tendencies to use acting out manifested as forgetting about the scheduled sessions, resistance to change setting agreements, becoming “deaf" to patients' transference, psychoanalyst's libidinal disinvestment, "loss in advance" and "the dead mother" countertransference, which were explained in terms of counter-phobic disinvestment, regression, work of denial and work of grief due to real losses, as well as the possible consequence of previous distortions of psychoanalytic stance.

Some practitioners comment on their first experience of working remotely due to the COVID-19 pandemic and the lockdown. E. Malater (2020) reports on the specifics of providing practice through the ZOOM platform, where the patient does not need to stand up from a couch, but rather needs to press the button "leave the meeting" twice, which signifies sessions as "meetings", and exposes the topic of "endings" (there is also a button for psychoanalyst "end meeting for all”). R. Rizq (2020) describes her feeling of loss and also highlights the risk to lose the loss by ignoring a number of losses associated with the impossibility to meet in person, i.e. loss of physical presence, of silence, of another type of distancing which allowed to manifest a sensitivity to otherness.

Consideration of not only partial, unique, or specific, but also general observations when practicing psychoanalysis and psychoanalytic psychotherapy during COVID19 unfolding, as well as some possible regional aspects, may also be significant.

The objective of this paper is to present the specifics of psychoanalysis and psychoanalytic psychotherapy in the context of the COVID-19 pandemic and quarantine in Ukraine, based on the results of an anonymous online survey of Ukrainian psychoanalysts and psychoanalytic psychotherapists from different institutions, associations, and theoretical schools.

Method. The anonymous online survey was developed for practitioners in psychoanalysis and psychoanalytic psychotherapy (including candidates) from Ukraine, with the possibility of further quantitative and qualitative data analysis. The study was reviewed and approved by the Local Ethics Committee of the Practical Psychology Department of Kryvyi Rih State Pedagogical University (Kryvyi Rih, Ukraine).

The study was conducted almost a month after the quarantine in the country had been imposed (on March 16), and aimed to assess the observed phenomena of the psychoanalytic process. The respondents were representatives of various associations, were working in different theoretical approaches, and held a range of professional statuses (i.e., candidates, certified psychoanalysts or psychoanalytic psychotherapists, training psychoanalysts, supervisors).

From April 8 to 15, 2020, the participants were asked via the Internet (announcements in social networks, through professional associations, by e-mail) to answer several questions anonymously in an online form, and were also informed that the aim of the survey was this research. Consents for gathering personal data, participating in the study, and publishing the results were also signed via the Internet before filling in the survey form.

The following groups of questions were proposed:

1) general professional data: method or methods of practicing (psychoanalysis, psychoanalytic psychotherapy, or both); years of practical experience; membership in psychoanalytic associations; status of specialist (candidate, psychoanalyst, training psychoanalyst, supervisor); types of patients the practitioner typically works with (adults, adolescents, children, groups);

2) current professional data: whether the respondent has kept or suspended the practice during the quarantine; any increase or decrease in the number of patients and sessions per week; having previous experience in conducting sessions remotely; the feeling of support from the colleagues during the quarantine or not; receiving guidelines from associations for working in COVID-19 pandemic conditions or not;

\section{3) observations from practicing during the}

quarantine: appearance of new topics in patients' speech; emergence of any new feelings within patients; changes in transference and countertransference; changes in the specifics of supervision; other observations.

For those who mentioned that they had suspended their practice due to the quarantine were proposed some 
further questions regarding their reasons for suspending, and how they spent their time instead of working.

Data analysis of this study includes descriptive Analyzants (patients) with whom the survey respondents are practicing

statistics, non-parametric comparison by $\chi^{2}$ for frequencies analysis, Spearman rank one-tail and two-tail correlation using IBM SPSS Statistics software, and the dichotomic correlation coefficient $\varphi$. Multiple response analysis was used for variables with patients' description.

Results. The responses were obtained $(\mathrm{n}=71)$ from certified psychoanalysts and psychoanalytic psychotherapists $(63.4 \%)$, training psychoanalysts (7\%), supervisors (9.9\%), and practicing candidates for psychoanalytic certification (19.7\%). Practitioners noted their work experience as being from 1 to 25 years $(\mathrm{M}=9.45, \mathrm{SD}=6.19$, mode $\mathrm{Mo}=10$, median $\mathrm{Me}=9$ ). Among them were female $(78.9 \%)$ and male $(19.7 \%)$ practitioners; 1 respondent indicated the sex as "other". Most survey participants (87.3\%) marked psychoanalytic therapy as the method they were practicing, wherein $53.5 \%$ of them practiced psychoanalysis. Therefore, $40.8 \%$ chose both methods.

If required, there was a possibility to choose multiple responses for the question about the common category of the analyzants or patients. The results of the multiple response analysis are presented in Table 1.

$91.5 \%$ of survey participants admitted their membership in one or more psychoanalytic associations. The distribution of mentioned associations is represented in Table 2 .

$81.4 \%$ confirmed perceived support of colleagues during the spread of COVID-19 and quarantine throughout Ukraine.

As for practicing during the quarantine, $83.1 \%$ of survey respondents noted they continued working. From this group of specialists, only $6.8 \%$ had never held any experience with remote sessions prior. $45.8 \%$ noticed they had some occasional experience, and $47.5 \%$ were highly experienced in practicing online or through the telephone. It was discovered that previous experience in working remotely had not affected attention paid to patients' feelings $\left(\chi^{2}=0.71\right)$, nor to the appearance of new topics during sessions $\left(\chi^{2}=0.59\right)$, transference $\left(\chi^{2}=0.42\right)$, and countertransference observations $\left(\chi^{2}=3.81\right)$. Interestingly, a moderate correlation was discovered between the duration of practice experience and whether practice did, in fact, continue dur-

\begin{tabular}{|l|c|c|c|}
\hline $\begin{array}{l}\text { Analyzants } \\
\text { (patients) }\end{array}$ & Responses (n) & Responses (\%) & Cases (\%) \\
\hline Adults & 70 & 51.1 & 98.6 \\
\hline Adolescents & 31 & 22.6 & 43.7 \\
\hline Children & 19 & 13.9 & 26.8 \\
\hline Groups & 17 & 12.4 & 23.9 \\
\hline Total & 137 & 100 & 193 \\
\hline
\end{tabular}

Table 2

\section{Distribution of membership in psychoanalytic} associations

\begin{tabular}{|l|c|c|}
\hline Institution of membership & Responses (n) & Responses (\%) \\
\hline $\begin{array}{l}\text { Ukrainian Association of Psychoa- } \\
\text { nalysis }\end{array}$ & 23 & 32.4 \\
\hline $\begin{array}{l}\text { Ukrainian Union of Psychothera- } \\
\text { pists }\end{array}$ & 23 & 32.4 \\
\hline $\begin{array}{l}\text { Ukrainian Psychoanalytic Union } \\
\text { European Confederation of Psy- } \\
\text { choanalytic Psychotherapies }\end{array}$ & 17 & 23.9 \\
\hline $\begin{array}{l}\text { Ukrainian Confederation of Psy- } \\
\text { choanalytic Psychotherapies }\end{array}$ & 14 & 23.9 \\
\hline $\begin{array}{l}\text { International Psychoanalytic Asso- } \\
\text { ciation }\end{array}$ & 4 & 19.7 \\
\hline $\begin{array}{l}\text { European Federation of Psychoana- } \\
\text { lytic Psychotherapies }\end{array}$ & 4 & 5.6 \\
\hline $\begin{array}{l}\text { Union of Psychologists and Psy- } \\
\text { chotherapists of Ukraine }\end{array}$ & 2 & 5.6 \\
\hline $\begin{array}{l}\text { Association of Psychotherapists } \\
\text { and Psychoanalysts of Ukraine }\end{array}$ & 1 & 2.8 \\
\hline \begin{tabular}{l} 
Group of Freud Field in Ukraine \\
\hline
\end{tabular} & 1.4 \\
\hline
\end{tabular}

ing the quarantine $(\mathrm{r}=0.372, \mathrm{p}<0.01)$. Besides, the practice was more likely to be continued in the case when the clients were adults $(\mathrm{r}=0.265, \mathrm{p}<0.05)$.

$55.9 \%$ said they were keeping their regular setting, including financial agreements, while $44.1 \%$ had implemented some setting changes. The distribution of decisions to keep or change the format was similar among the groups of practitioners with different professional statuses $\left(\chi^{2}=3.88\right)$.

According to the content analysis of responses regarding the changes in format or setting, the implemented modifications are as follows (in order from the most to 
DOI (Issue): https://doi.org/10.31108/1.2021.7.1

the least frequently noted):

1. Financial re-agreements. Practitioners noted different kinds of changes in financial aspects of the setting, including delayed payment ("credit" for sessions during the quarantine), partial payment (wherein the last part will be paid after the quarantine), reduction of the regular fee, cancellation of the session pass payment rule, and bank transfers instead of cash. Many of them mentioned the financial uncertainty or losses of analyzants as the main reason for such re-agreements.

2. Conducting sessions remotely. The respondents noted that they were continuing their work online, and some of them even mentioned the way in which they were doing it (kept working as if "on the couch" by switching the video off or changed to face-to-face video format). As was mentioned above, in some cases it was a new experience for the patient, while for others it was just continuing the previous remote format.

3. Reduction in the number of sessions per week. Practitioners mentioned they had changed the number of sessions per week for some analyzants, due to the latter's financial reasons or difficulties in participating in sessions remotely.

4. Suspension of the psychoanalytic process. With some analyzants, the process was paused for the duration of quarantine because of the impossibility to provide confidentiality in their homes.

As stated by the $59.3 \%$ of practitioners who responded, new topics associated with the quarantine and COVID-19 pandemic appeared during analyzants' sessions. Content analysis of the responses distributed these new patients' topics into 8 groups (Figure 1). the psychoanalyst's health, anxieties associated with being locked at home, and actual and existential anxieties about the patient's own life.

The topic "Quarantine restrictions" was devoted to discussions about the adherence to quarantine limitations and reactions to isolation, including frustration by it, ways to take care of one's self and to defend against danger, and compulsive defensive behavior.

The topic "Affective and regressive reactions" included different states and feelings that had significantly changed in the patient's opinion, i.e., aggression, disappointment, relief connected to previous guilt, feeling of loss, regressive states, narcissistic emptiness.

The topic "Origins of the pandemic" was devoted to the patient's thoughts about the pandemic, its meanings, its emergence, and included conspiracy theories.

The topic "Uncertainty and disruption of orderliness" included patients' descriptions of powerlessness, helplessness, uncertainty, and other discomforts associated with the pandemic in general, and the disruption of orderliness and the routine within their everyday lives.

The topic "Relationships" referred to the patient's discussions of conflicts with others (e.g., family members), and their consequential feelings of either closeness or loneliness manifested due to the quarantine situation.

What was not less important, were topics on individual "Financial difficulties" and "Other topics" which appeared as unique themes, e.g., gratitude to the psychoanalyst for continuing the psychoanalytic process, the freedom to think and speak, a feeling of self-transformation.

$89.5 \%$ of surveyed practitioners noted that their patients experienced new or a perceivably increased level

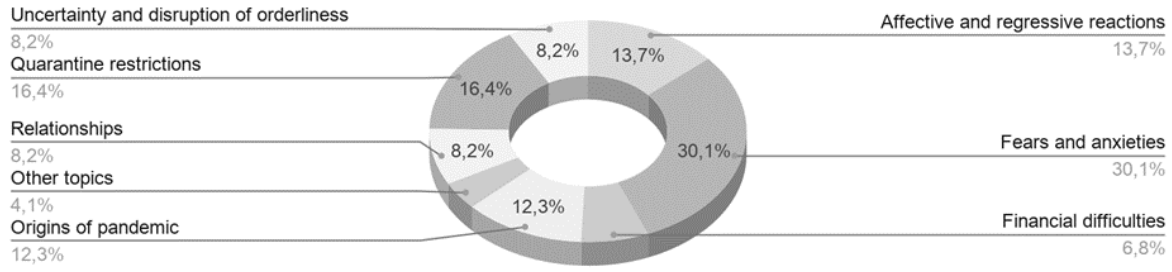

Figure 1. New topics on sessions

The topic "Fears and anxieties" consisted of fear of infection, fear of death (including also the death of some other people), fear about the future, fear about what the psychoanalyst thought of the patient's house, anxiety about of feelings. It was very difficult to summarize or amalgamate all the diversities of feelings into some groups. Thus, we can conclude that there were feelings and states which were mentioned more frequently. Such "top-feelings" were: 
Fears (mentioned in $49.2 \%$ of practitioners' responses): of infection, of death, of uncertainty, of closeness, of the future, of losing control, of losing Internet connection during the session;

Anxiety (37.3\%) without any particular frightening objects, additionally manifested in some cases through panic attacks;

Feeling of "being castrated" (18.6\%), i.e., powerlessness, helplessness, disorientation, insecurity, self-doubt; Aggression (15.3\%) and anger;

Hope-hopelessness $(13.6 \%)$ as a continuum of feelings.

About a half $(48.3 \%)$ of respondents observed some changes in the transference of their patients. Interestingly, part of them noted they had difficulties in describing and explaining the changes they felt. Among transferential observations, 4 points were the most common:

Regression and search for the strong Other: analyzants and patients demand or provoke the psychoanalyst to be someone who can protect them, give answers, take responsibility, and prove to have a strong personality. In some cases, this need for the strong, omnipotent Other inclines patients to moderate their previous negative transference, and to become more careful with the analyst.

Anxiety: patients manifest their general anxieties or anxieties associated with previous traumatic experience in the transferential relationships, e.g., wanting to see the psychoanalyst's eyes, being worried about the safety and security of the new analytic situation, etc.

Intensiveness of transference: previously developed transference becomes more intensive and perceived.

Negative feelings: dissatisfaction associated with the pandemic and/or the quarantine allowed patients to express reproach and resentment towards the psychoanalyst as a weak, unreliable, and betraying object.

Interestingly, a significant difference was found in transference interpretation due to certification status: practitioners who had not yet been certified (i.e., candidates or psychoanalytic consultants under supervision), tended to notice changes in the patient's transference more frequently than certified psychoanalysts and psychoanalytic psychotherapists $\left(\chi^{2}=8.21, \mathrm{p}<0.01\right)$.

Countertransference. $45.8 \%$ of practicing survey participants noticed some changes in their countertransfer- ence, which were then separated into three main groups (Figure 2).

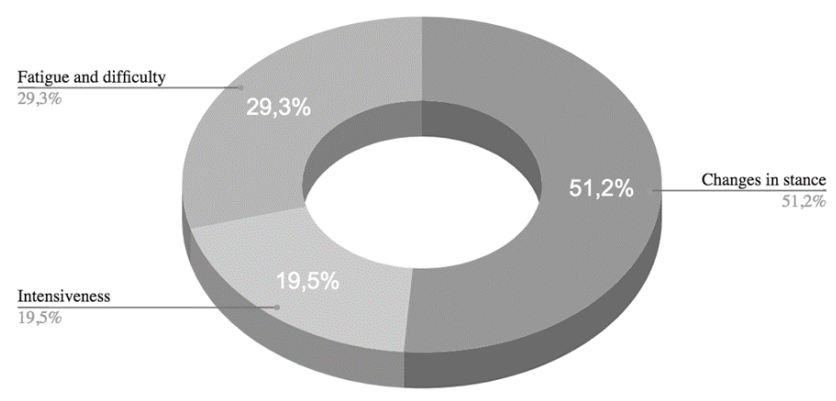

Figure 2. Changes in countertransference

Changes in psychoanalytic stance. As practitioners noted, they became more supportive, careful, cautious, manageable, through feeling something close to "primary maternal preoccupation" (in Winnicott's terms, 1957), wherein they were ready to give advice and reduce the regular fee (e.g., because of feeling guilty).

Fatigue and feelings of heaviness. In different wordings, psychoanalysts and psychotherapists spoke about the feeling of heaviness, fatigue, stress, and anxiety due to the quarantine and the remote format.

Intensiveness. These responses confirmed some perceivable changes in countertransference, including a higher intensiveness of countertransferential experiences. However, psychoanalysts could not clearly describe or summarize them at that stage.

The distribution of responses on whether countertransference had changed or not was similar in groups of respondents with different professional status $\left(\chi^{2}=0.46\right)$, and was not impacted by an increase or decrease in the number of patients $\left(\chi^{2}=0.02\right)$. At the same time, more experienced (in years) practitioners tended to confirm changes in their countertransference more often $(\mathrm{r}=0.33, \mathrm{p}<0,05)$. Responses which admitted some new aspects in countertransference moderately correlated with the observed new topics during sessions with patients $(\varphi=0.39, \mathrm{p}<0.01)$. Interestingly, correlation was also discovered between the observed changes in countertransference and the fact that the practitioner had obtained guidance from his or her association on how to practice during the pandemic and the quarantine $(\varphi=0.31, \mathrm{p}<0,05)$.

Supervision. $69.5 \%$ of practicing survey partici- 
pants noted that they continued to supervise their work on the regular schedule. Moderate correlation between changes in the practice setting and changes in supervision support (i.e., frequency, topics, format) was discovered $(\varphi=0.38$, $\mathrm{p}<0.01)$. On the contrary, those who had already held experience in practicing remotely before the quarantine tended to speak about changes in supervision less often $(\varphi=-0.33$, $\mathrm{p}<0.05)$.

Those who had received guidance from their associations on the practice during the pandemic were overall more likely to feel support from colleagues $(\varphi=0.43$, $\mathrm{p}<0,01)$. Support from colleagues was also a more common response from those who practice psychoanalytic psychotherapy $(\varphi=0.24, p<0,05)$, although support from associations in the form of guidance was similar for practitioners of both methods $\left(\chi^{2}=0.18\right)$.

Other specific observations. $16.9 \%$ of practitioners decided to add some extra information about their observations in a special open question "If our questions did not address everything, or you have something important you'd like to include regarding your observations, please write it here."

As for practice, it was reported that the demand for psychoanalytic support had grown, however people often could not afford it. There were noted observed difficulties for some patients who had previously used compulsive activity and personal distancing to avoid facing some inner and intersubjective processes; now they suffered because of the "immobility" initiated by the quarantine and the necessity to be with other people (e.g., their children) nearby. There were also some patients with usual anxieties who did not, in fact, feel any anxiety in the context of the pandemic. An additional topic was related to the significance of changes in the setting, including financial agreements, in order to support a connection to reality and save the analytic process where possible.

As for practitioners themselves, sensorial deprivation and loss of control over the space (room, conditions) during remote sessions were mentioned as difficult to bear. One respondent noted some perceivable changes in her defenses: shift to isolation of affect and using physical training to cope with her own anxiety. Another specialist wrote about the feeling of being united with friends and relatives, i.e., the relationships had become closer and warmer. A group analyst, after four sessions conducted online, concluded that online group analysis is indeed possible.

In accordance with survey responses, $15.5 \%$ of the specialists interrupted their practice due to the quarantine. Among the reasons, they listed:

patients' decisions, partially due to the lack of possibility to participate in sessions online or to pay for them because of financial losses;

practitioner's convictions against remote practice (sometimes only with certain patients);

limitations to conduct psychoanalytic sessions, e.g., due to issues of keeping confidentiality while working from home, and the impossibility of remote work with patients who are children.

These respondents noted they were spending this time having a rest, being with their families, reading, learning, educating and supervising others, caring for their own health. One respondent in particular admitted that she had started to work online in her previous specialization.

Discussion. Through summarizing the aforementioned results in regards with the observed specifics of practicing, we can conclude that Ukrainian psychoanalysts and psychoanalytic psychotherapists have obtained rather differing experiences during the COVID-19 pandemic unfolding and quarantine. However, some general tendencies were found.

First of all, the majority of studied specialists did, in fact, continue their practice $(83.1 \%)$ under the new conditions. As we have described earlier, a moderate correlation was found between the duration of practice experience and the fact that practice continued during the quarantine. We can interpret this in two possible ways. The first is about the number of analyzants or patients in current practice, which may differ between more or less experienced practitioners. Those who have worked longer may have enough patients to continue their practice even if a few of them had suspended their work. Those who have worked less may normally have just a few patients, and therefore the quarantine could pose a risk to lose them - at least temporarily. However, it is impossible to verify this hypothesis within the scope of the current study. The second is about the amount of professional experience in dealing with the patients' intentions to suspend or interrupt psychoanalysis 
and psychotherapy. Those who have more years under their belt may be more experienced in detecting some patients' resistance or acting out masked in "unavoidable hindrances to continue analysis", and therefore in working it through. The same could be stated about psychoanalyst's own resistance to continue working with damaged inner balance between destructiveness and love due to persecutory reality of pandemic (Kegerreis, 2020), with de-libidinized and devitalized analytic erotic field due to impossibility to conduct sessions in person (Elise, 2020), with obsessive topic of death, masked in the topic of «endings» (Malater, 2020), sharing the unforeseen crisis for both the patient and the psychoanalyst (Bronstein, 2020), as well as facing psychoanalyst' own regression, castration and difficulties in investing psychically in their patients (Velykodna, 2021). Thus, more seasoned practitioners may be more prepared to work through or to bear their own negative and depressive feelings in order to continue working psychoanalytically. For instance, using good-humored grace and accepting psychoanalyst's dispositional shift to be more facilitative to some treatments (Aibel, 2020).

Besides, a weak tendency was discovered wherein the practice was more likely to be continued in case of the clients being adults. We suppose it may be connected with (a) the objective difficulties in organizing and providing remote sessions for children, adolescents, and groups, and (b) the fact that work with all the just-listed patients in-

Table 3

\section{Observed changes in psychoanalytic practice during the unfolding of COVID-19}

\begin{tabular}{|l|l|l|}
\hline \multicolumn{1}{|c|}{ Studied category } & \multicolumn{2}{|c|}{$\begin{array}{c}\text { Are there any } \\
\text { changes?* }\end{array}$} \\
\hline & Yes & No \\
\hline Setting and format & $44.1 \%$ & $55.9 \%$ \\
\hline Patients' feelings & $89.5 \%$ & $10.5 \%$ \\
\hline Topics at the sessions & $59.3 \%$ & $40.7 \%$ \\
\hline Transference & $48.3 \%$ & $51.7 \%$ \\
\hline Countertransference & $45.8 \%$ & $54.2 \%$ \\
\hline Supervision & $30.5 \%$ & $69.5 \%$ \\
\hline
\end{tabular}

* The percentage is counted from $100 \%$ of respondents who continue their practice $(n=59)$ volves other people (i.e., parents, group members), thereby includes the others' resistance and acting out which would be harder to consider and to work through.

In the practicing group of respondents, as is shown in Table 3, the categories of observations were mostly distributed as half-to-half. Therefore, the obtained qualitative conclusions about these points (topics during the sessions, transference, countertransference) are not representative in relation to the whole sample. Only the category "Patients' feelings" reached an agreement level of $75 \%$.

Interestingly, "Patients' feelings" was the only category where we failed to identify certain groups following the content-analysis, due to the variety of noted feelings being too wide to generalize and unite. However, we discovered some top-feelings, which were most frequently mentioned by respondents as associated with the pandemic and/or quarantine: fear, anxiety, feeling of "being castrated", aggression, hope-hopelessness. Observation of these and other new patients' feelings are widely described in clinical reports by psychoanalysts from other regions (e.g. Lima, 2020: Slone, 2020; Varela, 2020) as well.

Nevertheless, even the categories which did not reach an agreement level of $75 \%$ showed some peculiar connections or differences between them. In particular, a significant difference was found in the interpretation of transference (whether it had changed or not) due to the certification status; those practitioners who were not certified yet (i.e., candidates or psychoanalytic consultants under supervision) tended to notice changes in patient's transference more frequently than the certified ones. As we suppose, it may be connected with the observed intensiveness of transference, which helped less experienced practitioners (candidates) to acknowledge some aspects of transferential relations which had not been evident for them earlier. Furthermore, certified psychoanalysts, including trainers and supervisors, were less surprised with the transferential dynamics they had observed under the new conditions. However, this hypothesis does not answer the question of why it is connected not with the duration of working experience, but rather the certification status. Therefore, we must consider increasing attentiveness in relation to the discovery of the transferential side of the psychoanalytic process as well as enhanced readiness to focus on it, which may be distinctive to candidates during their certification process. Possi- 
bly in their training they are always asked by their supervisors about the transference of their patients, and need to have the correct answers in order to be "good candidates".

At the same time, more experienced practitioners (in years) tended to confirm changes in their countertransference more often. Comparing these results with the previous points on transference and correlation with patients' topics, we may conclude that more experienced practitioners tend to reflect on both dimensions in the psychoanalytic process more often - namely, what patients say and what psychoanalysts feel. Whilst less experienced practitioners and candidates are focused more on the transference line, which connects these phenomena together, and tend to attribute them mostly to the patient. Complementarity of the observed transferential and countertransferential changes, which is evident if we compare the results of the contentanalysis in these categories (see Table 4), also highlights this possible link between the described observations. Perhaps the practitioners with different levels of experience or certification status were talking about some similar processes, feelings, and states, but with varying emphasis regarding its interpretation and explanation as being more transferential or countertransferential.

Table 4

\section{The main changes in transference and countertransfer- ence during the COVID-19 pandemic and quarantine: results of content-analysis}

Transference

Regression and search for the strong Other, who is able to protect, give answers, take responsibility

Intensiveness

Anxiety

Increased negative feelings to the psychoanalyst as a weak, unreliable and betraying object

As we can see from Table 4, while patients experience an urgent need in some regressive dynamics near a strong and protective Other, psychoanalysts observe their intentions to become more supportive and caring. Besides, both share some perceivable intense feelings in their transference-countertransference links. Similarly, we may suppose that patients' increased negative feelings and anxieties are related to the observed fatigueness and heaviness which practitioners did feel.

Another interesting fact was that the observed changes in countertransference were moderately correlated with the observed new topics from patients during sessions. However, based on this result, we cannot be sure which variety may be posed as the reason for the second variety, i.e., whether the attentiveness to the psychoanalyst's own countertransference and confirmation of changes in it makes the practitioner more attentive to changes in patient's topics, or the patient, talking more about the pandemic or the quarantine, evokes new or increased feelings and wishes in the psychoanalyst. Nevertheless, the observed shifts in countertransference experience and usage seem close to the noticed ones by other practitioners (Aibel, 2020; Rizq, 2020; Velykodna, 2021).

Surprisingly, a correlation was also discovered between the observed changes in countertransference and the fact that practitioners had received guidance from their association on how to practice during the pandemic and the quarantine. This puzzling result raises a question which is not possible to answer within in the current scope of the study: whether such a correlation is connected with some direct guidelines for association members to track their own countertransference dynamics, with associations' admitting that the COVID-19 pandemic and quarantine are new extraordinary situations, and therefore, causing these practitioners to be more likely to accept their own new feelings instead of work of denial, etc. These are just several of the dozens of possible reasons.

At first sight, it seemed trivial to discover that practitioners who had guidance from associations about the practice during the pandemic were overall more likely to feel support from colleagues. However, the perceived support from colleagues was a more common response from those who practiced psychoanalytic psychotherapy than from those who practiced psychoanalysis, although the distribution of support from associations in the form of guidelines was similar for practitioners of both methods. Do psychoanalytic psychotherapists build warmer and more supportive 
DOI (Issue): https://doi.org/10.31108/1.2021.7.1

relationships with colleagues? Are modern psychoanalysts in Ukraine somehow involved in "the tradition of arrogance" in psychoanalysis, as described by D. Shah (2018)? These questions are also beyond the scope of this study. Nevertheless, it seems important to study the current needs and vulnerabilities of psychoanalysts to build more supportive and trustable professional relationships, as M. A. Ellis (2020) recently emphasized.

One more interesting result was discovered regarding practicing remotely, wherein experience or inexperience did not affect psychoanalytical practitioners' ability to observe new topics, feelings, and transferential dynamics of patients, as well as their own countertransference. It may then prove the idea that psychoanalysis or psychoanalytic function in particular is more independent from the situation of meeting in person or online than we previously supposed. However, this point is still debatable (e.g., Malater, 2020; Rizq, 2020) and needs to be studied separately.

Conclusions. The current unavoidable COVID-19 situation may affect psychoanalytic practice - at least in its setting and format - which has always been understood as a significant frame, and even as "the third", of psychoanalysis. That is why specific clinical observations of unfolding unconscious processes which may be manifested during psychoanalytic sessions and relevant setting and technique modifications in this period are of extreme importance.

The results of the Ukrainian psychoanalysts' and psychoanalytic psychotherapists' survey have shown that the majority of respondents tried to continue their practice in new pandemic conditions, which was more successful with the more experienced (in years) practitioners and in the case when their patients were adults. However, $\square$ of the respondents had to suspend their practice due to the quarantine.

Almost half of the psychoanalysts and psychotherapists implemented some setting or format changes due to the COVID-19 unfolding. These were predominantly financial re-agreements, including the reduction or long delay of payment, shifting to the remote format of sessions, and a reduction in the number of sessions per week; however with some analyzants, the process was suspended due to the quarantine restrictions.
Those who continued practicing noted rather unanimously that their patients had experienced new intense feelings in particular those of fear, anxiety, being "castrated", aggression and anger, along with hope and hopelessness although the variety of feelings was, in fact, extensive and included even relief and freedom. About a half of the respondents mentioned some changes in transference and countertransference, which we found complementary during the studied period, that was also associated with the duration of practical experience, certification status, guidelines from psychoanalytic associations, and patients' readiness to speak on pandemic-related or quarantine-related topics. While the majority of respondents confirmed perceived support from colleagues, it was chiefly dependent on associations' attentiveness and, surprisingly, the main method.

The heterogeneity of the obtained observations regarding most survey categories (i.e., setting, topics at the sessions, transference, and countertransference), with distribution close to half-to-half, not only shows the current significant role of every particular psychoanalyst who deals with the developing COVID-19 in their own way (as well as his or her therapeutic flexibility; Bugliani, 2020), but also raises the question of a possible splitting in the psychoanalytic community, reflecting the unconscious response from the population towards the viral danger (Johanssen, 2020).

Limitations. This study has certain limitations, which we associate with the size and specifics of the sample. There is some imparity in the gender distribution of the surveyed psychoanalysts (78,9\% females, $19,7 \%$ males $)$. However, this corresponds with the data obtained from studies on psychotherapists from the Czech Republic, Slovakia, and Germany (77,8\% females; Humer \& et al., $2020)$, Croatia ( $88,6 \%$ females), the Balkan region $(89,2 \%$ females; Bagaric, Jokic-Begic, 2020), as well as on psychologists and psychotherapists from Ukraine (90,3\% females; Velykodna, Frankova, 2020). These data may describe some common gender asymmetry in psychoanalytic practice and in psychological occupations in the region of Eastern Europe.

Besides, the sample size may be somewhat smaller than expected samples for nationwide surveys for psycho- 
DOI (Issue): https://doi.org/10.31108/1.2021.7.1

therapy practitioners. We suppose that there are at least two reasons for it. Firstly, there are not many psychoanalysts and psychoanalytic psychotherapists in Ukraine. For instance, on the website of the Ukrainian Association of Psychoanalysis (ECPP national branch) only 27 people are listed as certified psychoanalysts, training analysts, or supervisors, and 9 more are listed as practicing candidates for certification. The website of the Ukrainian Union of Psychotherapists (EAP national branch) provides information about 98 certified psychoanalysts, training analysts, and supervisors. The website of the Ukrainian Psychoanalytic Society (IPA member from Ukraine) provides a list of 25 psychoanalysts, training analysts, supervisors, and candidates. The second reason may be related to the fact that the most frequently mentioned associations of membership are those of which the authors of this paper are members, too. Although we tried to involve for participation in the survey a wider group of psychoanalysts and psychoanalytic psychotherapists, perhaps it was still easier to reach our colleagues. At the same time, it may also refer to "alienation" and prove the splits in psychoanalytic societies, recently described by M. L. Ellis (2020); representatives of other associations might have been merely less enthusiastic to participate in a research conducted by somebody from other professional communities.

\section{References :}

Aibel, M. (2020). The joy of the session (notes from the pandemic quarantine). Attachment: Volume 14 Number 2 / Special Issue - Attachment in the Time of the Pandemic. pp. 193-203(11). doi: 10.33212/att.v14n1.2020.193

Bagaric, B., Jokic-Begic. (2020). Measuring therapists' attitudes toward integration of technology in psychotherapy and predicting their use of technology. Journal of clinical psychology. 2020; 1-22. doi: $10.1002 /$ jclp. 22967

Benvenuto, S. (2020). The virus and the unconscious. My Diary. European Journal of Psychoanalysis. Issue "Psychoanalysts Facing Coronavirus". Date of access 05/02/2020. Available at: https:// www.journal-psychoanalysis.eu/the-virus-and-the-unconsciousmy-diary/

Bolanos, J., Lucero J., Raz, F. B. (2020). A pandemized world: the human being in the face of its own exclusion as a species. European Journal of Psychoanalysis. Issue "Psychoanalysts Facing Coronavirus". Date of access 05/02/2020. Available at: https:// www.journal-psychoanalysis.eu/a-pandemized-world-thehuman-being-in-the-face-of-its-own-exclusion-as-a-species/
Blackman, J. S. (2020). A psychoanalytic view of reactions to the coronavirus pandemic in China. The American Journal of Psychoanalysis. 80(3). pp. 119-132. doi: 10.1057/s11231-020-09248-w

Bronstein, A. A. (2020). The case of J: Working as a psychoanalyst during the Pandemic. The International Journal of Psychoanalysis, 101 (4), 797-804. doi: 10.1080/00207578.2020.1799524

Bugliani, A. (2020). "You have to do this, and only this": a plea for clinical flexibility at the time of coronavirus. Attachment: Volume 14 Number 2 / Special Issue - Attachment in the Time of the Pandemic. pp. 214-226(13). doi: 10.33212/att.v14n2.2020.214

Catz, H., Ferruta, A., Francesconi, M., Goisis, P. et al. (2020). Fear of Lockdown Psychoanalysis, Pandemic Discontents and Climate Change. Publisher: Frenis Zero.

Dodds, J. (2020). Elemental Catastrophe: Ecopsychoanalysis and the Viral Uncanny of COVID-19. Stillpoint: Digital Magazine in the Eye of the Storm, Issue 004 (Apocalypse). Date of access 05/03/2020. Available at: https://stillpointmag.org/articles/ elemental-catastrophe-ecopsychoanalysis-and-the-viraluncanny-of-covid-19/

Elise, D. (2019). Creativity and the Erotic Dimensions of the Analytic Field. Routledge.

Elise, D. (2020). The Erotic Body. Psychoanalysis.Today. Issue 12 «The Body and Psychoanalysis».

Ellis, M. L. (2020). Dissenting colleagues; power, alienation, vulnerability. Psychodynamic Practice, 26:2, 124-135, doi: 10.1080/14753634.2020.1745677

Gentile, J. (2020). Time may Change Us: The Strange Temporalities, Novel Paradoxes, and Democratic Imaginaries of a Pandemic. Journal of the American Psychoanalytic Association. 68(4):649 -669. doi: 10.1177/0003065120955120

Humer, E., Pieh, C., Kuska, M., Barke, A., Doering, B. K., Gossmann, K., ... \& Probst, T. (2020). Provision of Psychotherapy during the COVID-19 Pandemic among Czech, Germanand Slovak Psychotherapists. International Journal of Environmental Research and PublicHealth, 17(13), 4811. doi:10.3390/ijerph17134811

Johanssen, J. (2020). Social Media and Coronavirus: Paranoid-Schizoid Technology and Pandemic? Human Arenas. doi: 10.1007/ s42087-020-00162-2

Kegerreis, S. (2020). Some thoughts on working psychoanalytically through the pandemic - The state of the good object. Psychodynamic Practice, 26:4, 364368, doi: 10.1080/14753634.2020.1830657

Klein, M. (1932). The psycho-analysis of children. London: Hogarth Press.

Lesley, M. (2020). Psychoanalytic Perspectives on Moral Injury in Nurses on the Frontlines of the COVID-19 Pandemic. Journal of the American Psychiatric Nurses Association.27(1). doi: $10.1177 / 1078390320960535$

Lima, C. D.; de. (2020). Psychoanalytical Investigation of Clinical Phe- 
DOI (Issue): https://doi.org/10.31108/1.2021.7.1

nomena in Psychosis, in the Pandemic Context of COVID-19. Psychology. 11(12):1837-1853. doi: 10.4236/ psych.2020.1112116

Lippin, R. (2020). The lockdown. Psychodynamic Practice. 26:3, 221226, doi: 10.1080/14753634.2020.1781331

Malater, E. (2020). The Logical Time of Ending a ZOOM Session as a Metaphor for the Terror of the Current Situation. European Journal of Psychoanalysis. Issue "Psychoanalysts Facing Coronavirus". Date of access 05/02/2020. Available at: https:// www.journal-psychoanalysis.eu/the-logical-time-of-ending-azoom-session-as-a-metaphor-for-the-terror-of-the-currentsituation/

McWilliams, N. (2020). Psychotherapy in a Pandemic. Psicoanalisi applicata alla Medicina, Pedagogia, Sociologia, Letteratura ed Arte. Date of access 05/02/2020. Available at: http://web.tiscali.it/ cispp/mcwilliamsPANDEMIC.htm

Rizq, R. (2020). What have we lost? Psychodynamic Practice, 26:4, 336344, doi: 10.1080/14753634.2020.1845068

Rossi, R.S., Ferro, M. (2020). Skype as a protected means to live a relationship. International Forum of Psychoanalysis, 29:3, 188191, DOI: 10.1080/0803706X.2020.1738549

Rowlandson, B. (2020). Cellos in the dark: managing attachment bonds in the time of Covid-19. Attachment: Volume 14 Number $2 /$ Special Issue - Attachment in the Time of the Pandemic. pp. 204-213(10). doi: 10.33212/att.v14n2.2020.204

Shah, D. (2018). Arrogance in countertransference. In Arrogance (pp. 115129). Routledge. doi: 10.4324/9780429429682-8

Sloane, J. (2020). Remote or close? Notes on working psychoanalytically by videoconference. Attachment: Volume 14 Number 2 / Special Issue - Attachment in the Time of the Pandemic. pp. 227241(15). doi: 10.33212/att.v14n2.2020.227

Steele, H. (2020). COVID-19, Fear and the Future: an attachment perspective. Clinical Neuropsychiatry, 17(2).

The Ukrainian Association of Psychoanalysis. Website. Date of access 09/08/2020. Available at: http://pa-uap.org/

The Ukrainian Psychoanalytic Society. Website. Date of access 09/08/2020. Available at: https://psy-a.in.ua/

The Ukrainian Union of Psychotherapists. Website. Date of access 09/08/2020. Available at: https://usp.community/register

Varela, Y. (2020). On the use of teleanalysis during COVID-19 in Panama. Psychoanalysis and Psychotherapy in China. 3(1):154-157. doi: 10.33212/ppc.v3n1.2020.154

Velykodna, M. (2021). Psychoanalysis during the COVID-19 pandemic: several reflections on countertransference. Psychodynamic practice. doi: 10.1080/14753634.2020.1863251

Velykodna, M., Frankova, I. (2020). Psychological and psychotherapeutic assistance during the COVID-19 pandemic: current challenges. In Psychosomatic Medicine and General Practice. Vol 5, Issue
Volume 7 Issue 1 (45) 2021

1, doi: 10.26766/PMGP.V5I1.213

Velykodna, M., Tsyhanenko, H. (2020). Which theories and conceptions do psychoanalysts and psychoanalytic psychotherapists consider helpful in their practice during the COVID-19 pandemic unfolding in Ukraine? Psychological journal. Issue 6(8), 88100. https://doi.org/10.31108/1.2020.6.8.7

Western, S. (2020). Covid-19: An intrusion of the Real The unconscious unleashes its Truth. Electronic Essay on Academia.edu. Date of access 05/02/2020. Available at: https:// www.academia.edu/42201252/Covid-

19_An_intrusion_of_the_Real_The_unconscious_unleashes_its -Truth

Winnicott, D. W. (1957). Mother and child: A primer of first relationships.

Yuran, A. (2020). On tendencies manifested by COVID-19. Psy.Media. Date of access 05/08/2020. Available at: https://psy.media/aiten -yuran-o-viruse/

Zangrilli, Q. (2020). Coronavirus and Psychic Regression. Psicoanalisi e Scienza. Date of access 05/03/2020. Available at: https:// www.psicoanalisi.it/english/205936/

Zizek, S. (2020). Pandemic. COVID-19 Shakes the World. Cambridge: Polity.

Zwart, H. (2018). Vampires, Viruses and Verbalisation: Bram Stoker's Dracula as a genealogical window into fin-de-siècle science. Janus Head: Journal of Interdisciplinary Studies in Literature, Continental Philosophy, Phenomenological Psychology, and the Arts, 16 (2):14-53.

\section{Mariana Velykodna}

PhD, Clinical Psychologist, Psychoanalyst, Head of Division "Psychoanalytic Psychology and Psychotherapy» in National Psychological Association of Ukraine, Kyiv, Ukraine; Senior lecturer, Department of Practical Psychology, Kryvyi Rih State Pedagogical University, Kryvyi Rih (Ukraine)

\section{Halyna Tsyhanenko}

PhD, Psychologist, Senior Researcher, Associate Professor, State University of Economics and Technology, Kryvyi Rih (Ukraine)

\section{PSYCHOANALYSIS AND PSYCHOANALYTIC PSYCHOTHERAPY IN UKRAINE DURING THE COVID-19 PANDEMIC UNFOLDING: THE RESULTS OF PRACTITIONERS' SURVEY}

\section{ABSTRACT}

The current unavoidable COVID-19 situation may affect psychoanalytic practice - at least in its setting and format - which has always been understood as a significant frame, and even as "the third", of psychoanalysis. That is why specific clinical observations of unfolding unconscious 
Psychotherapy, Psychoanalysis, Ukraine.

\section{Великодна Мар'яна Серхіївна}

Кандидат психологічних наук, психоаналітик, клінічний психолог, модератор Дивізіону "Психоаналітична психологія $і$ психотерапія" Національної психологічної асочіачії України, старший викладач кафедри практичної психології Криворізького державного педагогічного університету, м. Кривий Ріг (Украӥна)

\section{Циганенко Галина Валентинівна}

Кандидат психологічних наук, практичний психолог, доцент, доцент Державного університету економіки $і$ технологій, м. Кривий Ріг (Україна)

\section{ПСИХОАНАЛІЗ І ПСИХОАНАЛІТИЧНА ПСИХОТЕРАПІЯ В УКРАЇНІ ПІД ЧАС РОЗГОРТАННЯ ПАНДЕМІЇ СОVID-19: РЕЗУЛЬТАТИ ОПИТУВАННЯ ПРАКТИКІВ}

cial re-agreements, including the reduction or long delay of payment, shifting to the remote format of sessions, and a reduction in the number of sessions per week; however with some analyzants, the process was suspended due to the quarantine restrictions.

Those who continued practicing noted rather unanimously that their patients had experienced new intense feelings in particular those of fear, anxiety, being "castrated", aggression and anger, along with hope and hopelessness - although the variety of feelings was, in fact, extensive and included even relief and freedom. About a half of the respondents mentioned some changes in transference and countertransference, which we found complementary during the studied period, that was also associated with the duration of practical experience, certification status, guidelines from psychoanalytic associations, and patients' readiness to speak on pandemic-related or quarantine -related topics. While the majority of respondents confirmed perceived support from colleagues, they were chiefly dependent on associations' attentiveness and, surprisingly, the main method.

The heterogeneity of the obtained observations regarding most survey categories (i.e., setting, topics at the sessions, transference, and countertransference), with distribution close to half-to-half, not only shows the current significant role of every particular psychoanalyst who deals with the developing COVID-19 in their own way, but also raises the question of a possible splitting in the psychoanalytic community, reflecting the unconscious response from the population towards the viral danger.

Keywords: Covid-19, Pandemic, Psychoanalytic

\section{АНОТАЦІЯ}

Неуникні обставини, викликані пандемією COVID-19, здатні суттєво впливати на психоаналітичну практику - принаймні на іiі сетинг та формат - що завжди розумілося як надважлива рамка, "третє" психоаналізу. Тому конкретні клінічні спостереження за розгортанням несвідомих процесів, які можуть проявлятися під час психоаналітичних сеансів, а також відповідні модифікації сетингу та техніки в цей період мають надзвичайне значення.

Результати опитування українських психоаналітиків та психоаналітичних психотерапевтів показали, що більшість респондентів намагалися продовжувати свою практику в нових пандемічних умовах, що було більш успішним у більш досвідчених (в роках) практиків. Однак $1 / 6$ респондентів була змушена припинити свою практику через карантин.

Майже половина психоаналітиків та психотерапевтів впровадила деякі зміни сетингу або формату через розгортання COVID-19. Це були переважно фінансові передомовленості, включаючи зменшення або тривалу затримку платежів, перехід на віддалений формат сесій та зменшення кількості сесій на тиждень; проте з деякими аналізантами процес був призупинений через карантинні обмеження.

Ti, хто продовжував працювати, досить одностайно відзначали, що їхні пацієнти відчували нові сильні почуття, зокрема почуття страху, тривоги, "кастрованості", агресії та гніву, а також надію та 
DOI (Issue): https://doi.org/10.31108/1.2021.7.1

безнадію, хоча різноманіття почуттів насправді було великим i включало навіть полегшення i свободу. Близько половини респондентів повідомили про деякі зміни у перенесенні та контрперенесенні протягом досліджуваного періоду, що також було пов'язано 3 тривалістю практичного досвіду, статусом сертифікації, рекомендаціями психоаналітичних асоціацій та готовністю пацієнтів говорити про теми, пов'язані 3 пандемією і карантином. Хоча більшість респондентів вказали на відчутну підтримку 3 боку колег, це головним чином залежало від уважності асоціацій i основного методу практики.

Неоднорідність отриманих спостережень щодо більшості категорій опитування (тобто сетингу, тем на сесіях, перенесення та контрперенесення), з розподілом близько 50/50, не лише показує значну роль кожного конкретного психоаналітика, який конструює власну індивідуальну відповідь на пандемію COVID-19, але також порушує питання можливого розщеплення в психоаналітичному співтоваристві, відображаючи позасвідому реакцію населення на вірусну небезпеку.

Ключові слова: Covid-19, пандемія, психоаналітична психотерапія, психоаналіз, Україна.

\section{Великодная Марьяна Сергеевна}

Кандидат психологических наук, психоаналитик, клинический психолог, модератор Дивизиона "Психоаналитическая психология $и$ психотерапия" Национальной психологической ассоциации Украины, стариий преподаватель кафедры практической психологии Криворожского государственного педагогического университета, 2. Кривой Рог (Украина)

\section{Циганенко Галина Валентиновна}

Кандидат психологических наук, практический психолог, дочент Государственного университета экономики и технологий, г. Кривой Рог (Украина)

\section{ПСИХОАНАЛИЗ И ПСИХОАНАЛИТИЧЕСКАЯ \\ ПСИХОТЕРАПИЯ В УКРАИНЕ ВО ВРЕМЯ \\ РАЗВОРАЧИВАНИЯ ПАНДЕМИИ СОVID-19: РЕЗУЛЬТАТЫ ОПРОСА ПРАКТИКОВ}

\section{АННОТАЦИЯ}

Неизбежные обстоятельства, вызванные пандемией COVID-19, способны существенно влиять на психоаналитическую практику - по крайней мере на еe сеттинг и формат - обычно понимаемые как важнейшая рамка, "третье" психоанализа. Поэтому конкретные клинические наблюдения за развитием бессознательных процессов, проявляющихся во время психоаналитических сеансов, а также анализ соответствующих изменений сеттинга и техники в этот период имеют чрезвычайное значение.

Результаты опроса украинских психоаналитиков и психоаналитических психотерапевтов показали, что большинство респондентов пытались продолжать свою практику в новых пандемических условиях, что было более успешным у более опытных (в годах) практиков. Однако 1/6 респондентов была вынуждена прекратить свою практику из-за карантина.

Почти половина психоаналитиков и психотерапевтов внедрила некоторые изменения в сеттинге или формате из-за разворачивающейся пандемии COVID-19. Это были преимущественно изменения финансовых договоренностей, включая уменьшение или длительную задержку платежей, переход на удаленный формат сессий и уменьшение количества сессий в неделю. Однако с некоторыми анализантами процесс был приостановлен из-за карантинных ограничений.

Ключевые слова: Covid-19, пандемия, психоаналитическая психотерапия, психоанализ, Украина.

\section{How to cite (як цитувати):}

Velykodna M., Tsyhanenko H. (2021). PSYCHOANALYSIS AND PSYCHOANALYTIC PSYCHOTHERAPY IN UKRAINE DURING THE COVID-19 PANDEMIC UNFOLDING: THE RESULTS OF PRACTITIONERS' SURVEY. PSYCHOLOGICAL JOURNAL, 7 (1), 20-33. https:// doi.org/10.31108/1.2021.7.1. 